\title{
Exon skipping during splicing of albumin mRNA precursors in Nagase analbuminemic rats
}

\author{
(Northern blot hybridization/polymerase chain reaction cDNA amplification/RNase protection)
}

\author{
Fouad Shalaby and David A. Shafritz
}

Marion Bessin Liver Research Center and the Departments of Medicine and Cell Biology, Albert Einstein College of Medicine, 1300 Morris Park Avenue, Bronx, NY 10461

Communicated by Matthew D. Scharff, December 28, 1989 (received for review November 29, 1989)

\begin{abstract}
Based on the observation that albumin transcripts accumulate in the liver nuclear RNA fraction of Nagase analbuminemic rats (NAR), it was proposed [Esumi, H., Takahashi, Y., Shigeaki, S., Nagase, S. \& Takahashi, S. (1983) Proc. Natl. Acad. Sci. USA 80, 95-99] that a 7-base-pair deletion at the splice donor site of intron H-I of the albumin gene in these animals leads to impaired processing of albumin pre-mRNA. To identify the specific splicing abnormality, we examined the primary structure of cytoplasmic albumin mRNA across the junctions of exons G-H-I by RNase protection mapping, Northern blot hybridization, Southern blot analysis of polymerase chain reaction-amplified cDNA, and DNA sequencing. The major albumin mRNA species in NAR showed precise deletion of exon $H$, suggesting that this exon was skipped during albumin pre-mRNA processing. Since the intron G-H splice donor and acceptor sites and exon $H$ sequence are normal, the finding of exon H skipping in NAR has important implications regarding the mechanism of splice site selection. Moreover, the NAR model provides an excellent system to study splicing in vivo in a higher animal.
\end{abstract}

Albumin is synthesized almost exclusively by the liver and is secreted into the serum of higher animals, where it represents $\approx 60 \%$ of total protein mass $(1)$. This protein plays a major role in maintenance of serum colloid osmotic pressure and transport of various substances, including bilirubin, fatty acids, metal ions, exogenous drugs, and xenobiotics. Several human kindreds have been reported with analbuminemia thought to be transmitted as an autosomal recessive trait (2, 3). However, despite the important functions of this protein, analbuminemic humans have only mild abnormalities, including occasional edema, elevated serum lipids, and increased erythrocyte sedimentation rates (2).

Nagase et al. (4) identified an analbuminemic rat and by subsequent breeding experiments established an analbuminemic rat strain, the Nagase analbuminemic rat (NAR). The serum albumin concentration in NARs was reduced to 5 $\mu \mathrm{g} / \mathrm{ml}$ [i.e., $\approx 7000$ times lower than normal (5)], and there was a 750 times decrease in liver cytoplasmic albumin mRNA (6). Accumulation of albumin mRNA precursors was also found in liver nuclei of NARs, suggesting impaired processing of albumin primary transcripts (7). Sequence analysis revealed a 7-base-pair (bp) deletion starting at nucleotide (nt) 5 of the 9th of 14 introns of the albumin gene between exons $\mathrm{H}$ and $I$ (8).

The specific mutation of the albumin gene in NARs is similar to that observed in the $\beta$-globin gene of many patients with $\beta$-thalassemia. In these individuals, mutations within the first $6 \mathrm{nt}$ of the first (9) or second (10) intron reduce activity or inactivate the splice donor site of the respective intron. This leads to use of a downstream intron cryptic splice site or

The publication costs of this article were defrayed in part by page charge payment. This article must therefore be hereby marked "advertisement" in accordance with 18 U.S.C. $\$ 1734$ solely to indicate this fact. upstream exon splice site and the resulting $\beta$-globin mRNAs either retain a portion of the intron or lose a portion of the exon $(9,10)$.

Because the cytoplasmic level of albumin mRNA in NARs is markedly reduced compared to normal rat liver, the specific defect in the mRNA has not previously been identified. In the present study, we have utilized RNase protection mapping, Northern blot hybridization with specific exon probes, and sequence analysis of polymerase chain reaction (PCR)-amplified and cloned cDNAs to determine the primary structure of the exon G-H-I region of albumin mRNA. The major species of cytoplasmic albumin mRNA in NAR liver shows a complete deletion of exon $\mathrm{H}$ and, therefore, occurs by a different mechanism from that observed in $\beta$ thalassemias. A small amount of normal albumin mRNA is also present in NARs ( $1 \%$ of total albumin mRNA) as well as a trace amount of a second mutant mRNA that retains the proximal $255 \mathrm{nt}$ of the intron H-I sequence (similar to $\beta$-thalassemia). Since the albumin gene is highly transcribed in rat liver and RNA samples are readily obtainable from nuclear and cytoplasmic fractions, the analbuminemic rat model represents an excellent system to study the mechanism and regulation of splicing in vivo in a higher animal.

\section{MATERIALS AND METHODS}

Experimental Animals. Breeding pairs of Sprague-Dawley rats genetically deficient in albumin production (NARs) were obtained from Nagase (4). Male NARs, $100-300$ g (body weight), were used throughout. Sprague-Dawley rats of the same body weight, obtained from Taconic Farms, were used as normal controls.

DNA Plasmids and Probes. Fig. 1 shows a map of rat albumin cDNA (11), indicating the positions of various probes used in this study. Plasmid pGAlb345 was constructed by subcloning a 345-bp rat albumin cDNA fragment between the Pst I site in exon G and HindIII site in exon I into plasmid vector pGem-4Z (Promega). Transcription of this plasmid by T7 RNA polymerase after linearization with EcoRI generates a 385-nt transcript of which $137 \mathrm{nt}$ are antisense sequences of the distal part of exon G, $133 \mathrm{nt}$ are antisense sequences of exon $\mathrm{H}$, and $75 \mathrm{nt}$ are antisense sequences of the proximal part of exon $I$. The remaining $40 \mathrm{nt}$ are vector sequences.

Plasmid pSP70-RHA was constructed by subcloning the $H$ HindIII-Pvu II fragment of plasmid pRHAlb ${ }_{2}$, a genomic rat-human albumin CDNA hybrid (unpublished data) into the vector pSP70 (Promega). The insert in pSP70-RHA contains 0.45 kilobase of rat albumin genomic sequences upstream of the cap site, $33 \mathrm{bp}$ of the rat albumin $5^{\prime}$ untranslated sequence, the first $18 \mathrm{bp}$ of the rat albumin cDNA coding sequence ( $100 \%$ homologous to the corresponding sequence in human albumin cDNA), and 255 bp of the 5 ' end of the

Abbreviations: NAR, Nagase analbuminemic rat; nt, nucleotide(s); PCR, polymerase chain reaction. 


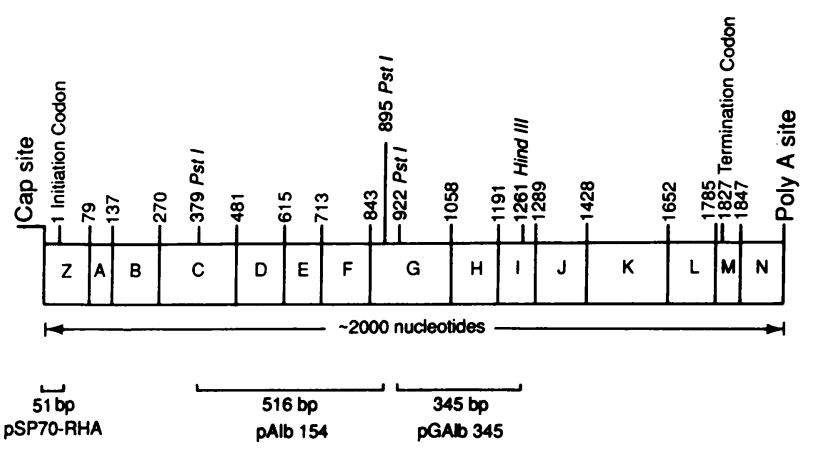

FIG. 1. Map of rat albumin cDNA. Exons are indicated by letters in the boxes. Relevant restriction endonuclease, transcription and translation initiation sites, and polyadenylylation sites, are indicated above the boxes. Sequences covered by the various probes used in the present study are indicated below.

human albumin cDNA coding sequence. Transcription of this plasmid with SP6 RNA polymerase after linearization with Nla IV generates a 383-nt transcript of which $51 \mathrm{nt}$ are complementary to the $5^{\prime}$ end of rat albumin cDNA. The remainder are antisense human albumin CDNA and vector sequences.

Isolation of Cytoplasmic Poly(A) ${ }^{+}$RNA. Freshly isolated liver was homogenized in $50 \mathrm{ml}$ of $0.25 \mathrm{M}$ sucrose $/ 75 \mathrm{mM}$ citric acid, $\mathrm{pH} 2.3 / 0.5 \%$ Triton $\mathrm{X}-100$ by using a Dounce homogenizer (12). The homogenate was filtered through four layers of cheesecloth and the filtrate was centrifuged at $\mathbf{2 0 0 0}$ $\times g$ for 10 min to remove nuclei. The supernatant fraction was then centrifuged at $20,000 \times g$ for $30 \mathrm{~min}$ and cytoplasmic RNA was extracted from the pellet by the method of Chomczynski and Succhi (13). Poly(A) ${ }^{+}$RNA was isolated from total cytoplasmic RNA by two passages through an oligo (dT)-cellulose column (14).

RNase Protection Mapping. Samples $(20 \mu \mathrm{g})$ of cytoplasmic poly $(\mathrm{A})^{+}$RNA were used for most studies. When smaller amounts were utilized, yeast tRNA was added to adjust total RNA to $20 \mu \mathrm{g}$. After ethanol precipitation, each RNA pellet was dissolved in $30 \mu \mathrm{l}$ of hybridization buffer [ $80 \%$ ( $\mathrm{vol} / \mathrm{vol})$ formamide/40 mM Pipes, $\mathrm{pH} 6.7 / 400 \mathrm{mM} \mathrm{NaCl} / 1 \mathrm{mM}$ EDTA] containing $5 \times 10^{4} \mathrm{cpm}$ of labeled antisense RNA probe prepared by transcription of EcoRI-linearized pGAlb345 or Nla IV-linearized pSP70-RHA with T7 or SP6 RNA polymerase, respectively, as described by Melton $e t$ al. (15). The solution was heated at $80^{\circ} \mathrm{C}$ for $4 \mathrm{~min}$ and then incubated at $60^{\circ} \mathrm{C}$ for $12-16 \mathrm{hr}(15)$. Buffer $(300 \mu \mathrm{l})$ containing $50 \mathrm{mM}$ sodium acetate (pH 4.5), 2 mM EDTA, and RNase T2 (15 units $/ \mathrm{ml}$ or 45 units $/ \mathrm{ml}$ ) was added for hybrids with pGAlb345 or pSP70-RHA, respectively. RNase digestion was performed for $1 \mathrm{hr}$ at $30^{\circ} \mathrm{C}$, after which protected RNA RNA hybrids were extracted with phenol/chloroform and precipitated with ethanol. The RNA pellet was dissolved in a formamide-denaturing buffer and analyzed by electrophoresis on a $6 \%$ polyacrylamide $/ 8 \mathrm{M}$ urea sequencing gel.

Southern and Northern Blot Analyses. DNA fragments were separated by electrophoresis on agarose gels and after alkaline denaturation and neutralization (16) were transferred to nylon membranes (GeneScreen, NEN) in $0.025 \mathrm{M}$ sodium phosphate ( $\mathrm{pH}$ 6.5). RNA was fractionated by electrophoresis on denaturing agarose gels containing $2.2 \mathrm{M}$ formaldehyde (16), transferred to nylon membranes in $0.025 \mathrm{M}$ sodium phosphate ( $\mathrm{pH}$ 6.5), and fixed by UV irradiation. Radioactive DNA probes were prepared by primer extension (17) and had specific activities of $1-10 \times 10^{8} \mathrm{cpm} / \mu \mathrm{g}$. An oligodeoxynucleotide probe specific for exon $\mathrm{H}$ was labeled at the $5^{\prime}$ end by $\left[\gamma_{-}{ }^{32} \mathrm{P}\right] \mathrm{ATP}$ and T4 polynucleotide kinase (16). Prehybridization and hybridization of DNA and RNA blots was per- formed under standard conditions (16) with posthybridization washing of filters at high stringency.

cDNA Synthesis and Amplification by the PCR. The first strand of CDNA was synthesized by reverse transcription using $10 \mu \mathrm{g}$ of poly(A) ${ }^{+}$RNA as template and avian myeloblastosis virus reverse transcriptase (16). After alkaline hydrolysis of template RNA and phenol/chloroform extraction, the cDNA was precipitated with ethanol. The pellet was dissolved in a solution containing $50 \mathrm{mM} \mathrm{KCl}, 10 \mathrm{mM}$ Tris $\cdot \mathrm{HCl}(\mathrm{pH} 8.3$ ), $1.5 \mathrm{mM} \mathrm{MgCl}, 0.1 \%$ gelatin, all four dNTPs (each at $200 \mathrm{mM}$ ), Thermus aquaticus DNA polymerase I (Perkin-Elmer/Cetus) at 2.5 units $/ \mathrm{ml}$, and the two oligodeoxynucleotides (each at $1 \mathrm{mM}$ ). One oligodeoxynucleotide was a 20-mer of antisense sequences 3 bp downstream of the HindIII site in the rat albumin exon I and the other was a 20-mer of sense sequences $3 \mathrm{bp}$ upstream of the Pst I site in exon G (see Fig. 1). Amplification was performed by incubating the mixture in a DNA Thermal Cycler (PerkinElmer/Cetus) for 30 cycles of denaturation $\left(1 \mathrm{~min}\right.$ at $\left.94^{\circ} \mathrm{C}\right)$, annealing $\left(2 \mathrm{~min}\right.$ at $\left.56^{\circ} \mathrm{C}\right)$, and extension $\left(3 \mathrm{~min}\right.$ at $\left.72^{\circ} \mathrm{C}\right)$. PCR products were digested with HindIII and $P$ st $\mathrm{I}$ and analyzed by electrophoresis on $1.5 \%$ agarose gels or subcloned into pGem- $4 \mathrm{Z}$ plasmid vector and sequenced by the dideoxynucleotide method using the Sequenase kit (United States Biochemical).

\section{RESULTS}

RNase Protection Mapping. Since the genetic abnormality in NAR had been identified as a 7-bp deletion near the $5^{\prime}$ splice donor site of intron $\mathrm{H}-\mathrm{I}$ of the albumin gene (7), it was important to examine the primary structure of cytoplasmic mRNA in the exon G-H-I region. To identify the specific splicing abnormality, a radioactive antisense RNA probe was generated by transcription of EcoRI-linearized plasmid pGAlb345 (Fig. 1). As shown in Fig. $2 A$, the probe is $\approx 383 \mathrm{nt}$ (lane 1), and in the absence of rat liver RNA it is completely degraded (lane 2). In the presence of normal rat liver cytoplasmic poly $(A)^{+}$RNA, a 345-nt fragment is protected from digestion with RNase T2 (lane 3). In contrast, cytoplasmic poly $(A)^{+}$RNA of NAR liver protected two major smaller fragments of 137 and $75 \mathrm{nt}$, respectively (lane 4). These fragments were comparable in size to the sequences of exons $G$ and I represented in the probe. The 345-nt fragment characteristic of normal rat albumin mRNA was also protected with NAR cytoplasmic poly(A) ${ }^{+}$RNA (lane 4) but was present at a level 50-100 times lower than the 137-nt band. These results indicate a difference in primary structure between normal albumin mRNA and the major species present in NAR liver. After correction for the amount of RNA used in each lane of the gel and the exposure times of the various lanes in the autoradiogram (see legend, Fig. 2), we concluded that the level of cytoplasmic albumin mRNA in NAR is $\approx 200$ times less than in normal rat liver.

To ensure that the different fragment patterns of RNasedigested hybrids in NAR vs. normal liver did not represent an experimental artifact, an antisense RNA probe generated from a different region of the albumin coding sequence (pSP70-RHA) was utilized (see Fig. 1). This probe covers the $5^{\prime}$ end of rat albumin mRNA. As shown in Fig. $2 B$, the probe is $\approx 383 \mathrm{nt}$ (lane 1 ) and was completely degraded by RNase T2 in the absence of rat liver RNA (lane 2). Both normal and NAR liver cytoplasmic poly(A) ${ }^{+}$RNAs protected the same size fragment of $51 \mathrm{nt}$ (lanes 3 and 4). Since 200 -fold more RNA was used from NAR liver (lane 3) as compared to normal rat liver (lane 4), protected bands of equal intensities were obtained.

Northern Blot Analysis. RNase protection mapping suggested deletion of most or all of the exon $\mathrm{H}$ sequence from albumin mRNA in NAR liver. To verify this conclusion, 


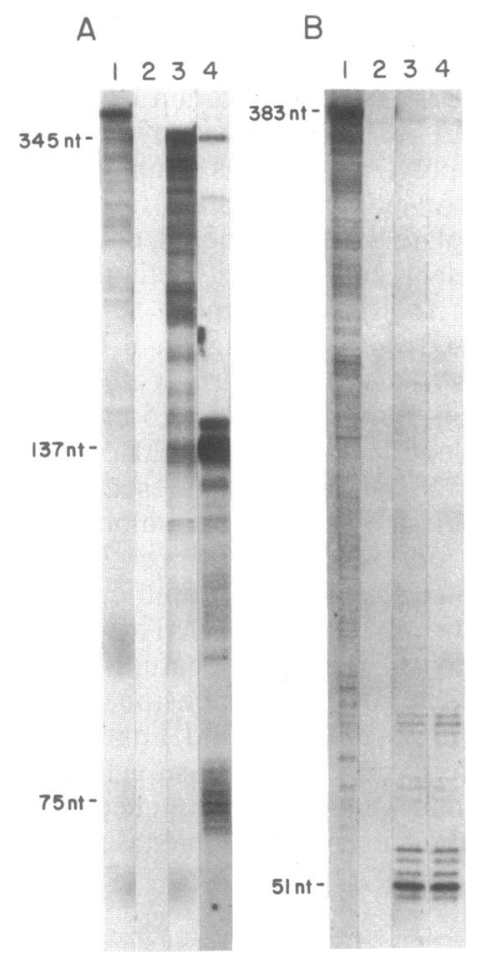

FIG. 2. RNase protection mapping of NAR liver albumin mRNA. (A) Lanes: 1, RNA probe synthesized by T7 RNA polymerase from EcoRI-linearized plasmid pGAlb345;2, fragments protected by $20 \mu \mathrm{g}$ of yeast tRNA; 3 , fragments protected by $1 \mu \mathrm{g}$ of normal rat liver cytoplasmic poly(A) ${ }^{+}$RNA and $19 \mu \mathrm{g}$ of yeast tRNA; 4 , fragments protected by $20 \mu \mathrm{g}$ of NAR liver cytoplasmic poly(A) ${ }^{+}$RNA, as determined by electrophoresis on a $6 \%$ polyacrylamide $/ 8 \mathrm{M}$ urea sequencing gel. Lanes 1,2 , and 3 are from a 12-hr exposure of the autoradiogram without intensifying screens and lane 4 is from a 48-hr exposure with two intensifying screens. $(B)$ Lanes: 1 , RNA probe synthesized by SP6 RNA polymerase from Nla IV-linearized plasmid pSP70-RHA; 2 , fragments protected by $20 \mu \mathrm{g}$ of yeast tRNA; 3, fragments protected by $0.1 \mu \mathrm{g}$ of normal rat liver cytoplasmic poly $(A)^{+}$RNA and $20 \mu \mathrm{g}$ of yeast tRNA; 4 , fragments protected by $20 \mu \mathrm{g}$ of NAR liver cytoplasmic poly(A) ${ }^{+}$RNA. Sizes of the fragments, indicated at the left, were determined by comparison with end-labeled fragments of pBR322 digested with Msp I.

replicate Northern blots (Fig. 3) containing $0.02 \mu \mathrm{g}$ of cytoplasmic poly $(\mathrm{A})^{+}$RNA of normal rat liver (lane 1) and $10 \mu \mathrm{g}$ of cytoplasmic poly $(\mathrm{A})^{+}$RNA of NAR liver (lane 2 ) were hybridized either to a normal rat albumin cDNA probe (Fig. $3 A$ ) or an exon $\mathrm{H}$-specific oligodeoxynucleotide probe (Fig. $3 B$ ). By using the albumin cDNA probe, a strong hybridization signal was obtained with either normal (lane 1) or analbuminemic (lane 2) poly(A) ${ }^{+}$RNA. However, with the exon $\mathrm{H}$-specific oligodeoxynucleotide probe, only a very weak signal $(\approx 1 \%)$ was obtained with analbuminemic (lane 2$)$ as compared to normal liver (lane 1 ) poly(A) ${ }^{+}$RNA. These results confirm near absence of exon $H$ sequences in NAR albumin mRNA.

Amplification and Analysis of Albumin Exon G-H-I cDNA Sequences. To identify the precise structural abnormality in NAR albumin mRNA at the nucleotide level, cloning and sequencing of albumin cDNA spanning the exon G-H-I region was needed. However, traditional methods of constructing a cDNA library and screening with radioactive probes were not feasible, because the steady-state level of albumin sequences in this RNA population was reduced several hundredfold. Therefore, the PCR was employed to amplify NAR liver albumin cDNA sequences spanning the exon G-H-I region. After HindIII and Pst I digestion, these PCR amplification products were analyzed by electrophoresis on a $1.5 \%$ agarose gel (Fig. 4). In the absence of rat liver

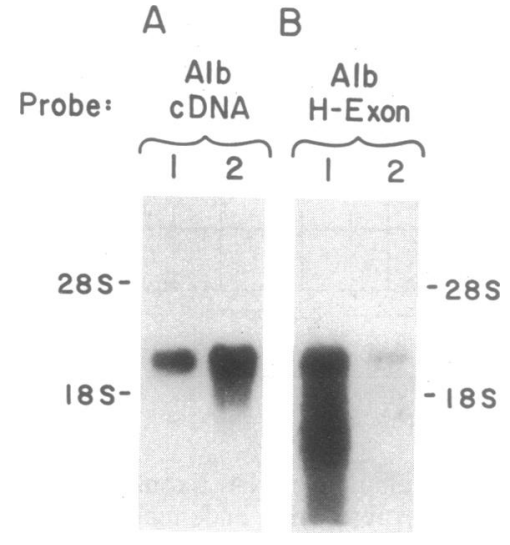

FIG. 3. Northern blot hybridization analysis of NAR albumin mRNA. RNAs were denatured, fractionated by electrophoresis on a formaldehyde/agarose gel (16), and transferred to duplicate nylon filters. $(A)$ Filter hybridized to a labeled 516-bp rat albumin cDNA probe (ref. 18 and Fig. 1). (B) Filter hybridized to a $5^{\prime}$ end-labeled exon $\mathrm{H}$-specific oligodeoxynucleotide probe comprised of a 28 -mer complementary to exon $\mathrm{H}$ sequences $13 \mathrm{nt}$ downstream of the intron $\mathrm{G}-\mathrm{H} /$ exon $\mathrm{H}$ splice junction. Lanes: $1,0.02 \mu \mathrm{g}$ of normal rat liver cytoplasmic poly(A) ${ }^{+}$RNA; $2,10 \mu \mathrm{g}$ of NAR liver cytoplasmic poly $(A)^{+}$RNA. The slightly slower mobility of the albumin mRNA band in lanes 2 probably results from the higher amount of RNA used in these lanes as compared to lanes 1 . The origin of low molecular mass hybridizing material in $B$, lane 1 , has not been determined, although it probably represents poly $(A)^{+}$RNA molecules partially degraded at their $5^{\prime}$ ends.

RNA in the reverse transcription step, no PCR amplification product was obtained (lane 1 ). In the presence of cytoplasmic poly $(\mathrm{A})^{+} \mathrm{RNA}$ from normal rat liver, the amplification product was $\approx 345 \mathrm{bp}$ (lane 3 ), exactly the same size as the amplification product of plasmid pAlb154 (18), containing normal rat albumin cDNA sequences spanning the exon G-H-I region (lane 4). In contrast, reverse transcription and amplification of cytoplasmic poly $(A)^{+}$RNA from NAR liver (lane 2) resulted in a PCR product of $\approx 212 \mathrm{bp}$. This difference in size approximated the length of exon $\mathrm{H}, 133 \mathrm{bp}$.

To show that the size difference in the PCR amplification products of normal vs. NAR albumin mRNA is actually due

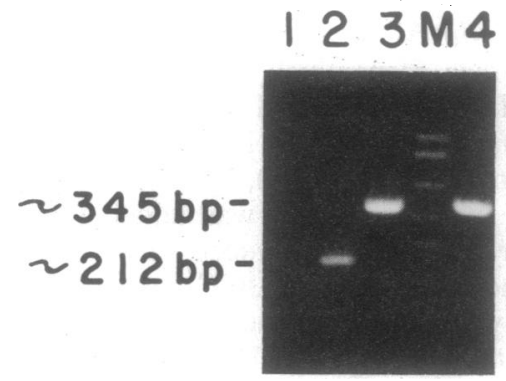

Fig. 4. Electrophoretic analysis of albumin cDNA sequences amplified by PCR. First-strand CDNA was synthesized by reverse transcriptase using an oligodeoxynucleotide primer complementary to a 20-nt sequence 3 bp downstream of the HindIII site in exon I and $10 \mu \mathrm{g}$ of cytoplasmic poly(A) ${ }^{+}$RNA from NAR liver (lane 2) or normal rat liver (lane 3) as template. In lane $1,10 \mu \mathrm{g}$ of yeast tRNA was used as template and, in lane 4,200 pg of plasmid pAlb154, containing exons $\mathrm{G}, \mathrm{H}$, and $\mathrm{I}$ of rat albumin CDNA (18), was utilized. The cDNA second strand was synthesized in the first cycle of PCR by using Thermus aquaticus DNA polymerase I and a second $20-n$ oligodeoxynucleotide primer, representing sequences 3 bp upstream of the Pst I site in exon G. PCR products were digested with HindIII and $P s t I$ and analyzed by electrophoresis on a $1.5 \%$ agarose gel. The products were visualized by ethidium bromide fluorescence. Approximate molecular sizes were determined by comparison with $M s p$ I fragments of pBR322 (lane M). 


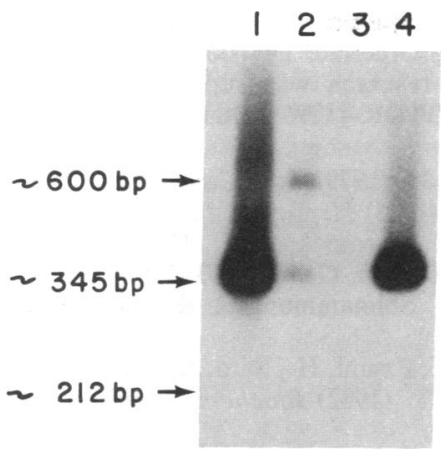

FIG. 5. Southern blot hybridization of PCR-amplified albumin cDNAs. cDNAs were synthesized, amplified, and electrophoresed on a $1.5 \%$ agarose gel, transferred to a nylon membrane filter, and hybridized to a 5 ' end-labeled exon $\mathrm{H}$-specific oligodeoxynucleotide probe (28-mer complementary to sequences 13 bp downstream of intron G-H splice acceptor site). Lanes: 1, PCR-amplified cDNA products of $10 \mu \mathrm{g}$ of normal rat liver cytoplasmic poly $(\mathrm{A})^{+} \mathrm{RNA} ; 2$, PCR-amplified cDNA products of $10 \mu \mathrm{g}$ of NAR liver cytoplasmic poly $(A)^{+}$RNA; 3 , amplified cDNA products of $10 \mu \mathrm{g}$ of yeast tRNA; 4, amplified cDNA products of $200 \mathrm{pg}$ of plasmid pAlb154 (18).

to deletion of exon $\mathrm{H}$ sequences from the $\approx 212-\mathrm{bp}$ cDNA species, cDNA amplification products from one such gel were transferred to a nylon membrane and hybridized to an exon $\mathrm{H}$-specific oligodeoxynucleotide probe. As shown in Fig. 5, the $\approx 345$-bp species obtained from either normal rat liver cytoplasmic poly(A) ${ }^{+}$RNA (lane 1 ) or plasmid pAlb154 (lane 4) hybridized very strongly to exon $H$ probe. The $\approx 212$-bp band obtained from NAR albumin mRNA did not give detectable hybridization with the exon $\mathrm{H}$ probe (lane 2); however, a very weak hybridization signal was observed at $\approx 345$ bp (lane 2). This probably represents a very small amount of normally spliced albumin mRNA in NAR liver. An additional weak band at $\approx 600$ bp was also detected in lane 2 and may represent a second abnormally spliced albumin mRNA species in NAR liver. Since this cDNA is $\approx 255$ bp larger than normal, it most likely represents an mRNA species retaining both exon $\mathrm{H}$ and intron $\mathrm{H}-\mathrm{I}$ sequences resulting from use of a cryptic splice donor site $255 \mathrm{bp}$ downstream of the mutated site in the NAR intron H-I.

Both the $\approx 345$-bp and $\approx 212$-bp albumin cDNA species obtained by reverse transcription and PCR amplification of normal and NAR cytoplasmic poly(A) ${ }^{+}$RNA, respectively, were cloned into plasmid vector pGem $-4 \mathrm{Z}$ and sequenced. The sequencing data (Fig. 6) showed precise deletion of exon $H$ with ligation of exon $G$ to exon $I$ in clones derived from NAR liver.

\section{DISCUSSION}

Although accumulation of albumin RNA sequences in liver nuclei of NAR (7) and identification of a 7-bp deletion at the splice donor site of intron $\mathrm{H}-\mathrm{I}$ of the albumin gene in these rats (8) suggested abnormal splicing within the G-H-I region, to our knowledge, the specific abnormality has not been identified. In the present study, four methods were used to examine the primary structure of albumin mRNA in NAR liver-namely, RNase protection mapping, Northern blot analysis, PCR amplification, and cDNA sequencing. Our results indicate that the exon $\mathrm{H}$ sequence is precisely deleted from most $(\approx 99 \%)$ albumin mRNA molecules in NAR. A small proportion of albumin mRNA molecules appears to have a normal primary structure and may be responsible for production of the small amount of serum albumin observed in these rats (5). PCR technology also identified another minor mRNA species in which the distance between the Pst I site in exon $G$ and the HindIII site in exon I was $\approx 600 \mathrm{nt}$. Since this is $\mathbf{2 5 5} \mathrm{nt}$ longer than the normal distance between these two sites, it most likely represents a second processing defect in which a cryptic splice site in intron $\mathrm{H}-\mathrm{I} 255 \mathrm{nt}$ downstream of the original site is utilized.

Use of cryptic splice sites as a result of mutations inactivating normally used sites is well documented in $\beta$ thalassemia $(9,10,19,20)$. When a $\beta$-globin gene with a single base substitution at position 1 of the second intervening sequence was expressed in HeLa cells, the predominant mRNA species utilized a cryptic splice site $47 \mathrm{nt}$ downstream of the original site and retained the proximal $47 \mathrm{nt}$ of the first intron (10). A second much less abundant mRNA species showed deletion of exon 2 . However, examples in which mRNAs with deleted exons represent the major species resulting from intron mutations are rare. In Chinese hamster ovary (CHO) cells, mutations at splice sites flanking exon 5 or at the splice donor site of exon 2 in the dihydrofolate reductase gene lead to skipping of the respective exons (21, 22). In osteogenesis imperfecta (23), a single base substitution changing the universal AG dinucleotide at the 3 ' end of intron 27 in the pro- $\alpha_{2}(\mathrm{I})$ collagen gene to GG also leads to deletion of exon 28 from mature pro- $\alpha_{2}(\mathrm{I})$ collagen mRNA. A similar AG to GG mutation at the $3^{\prime}$ end of intron 20 of the retinoblastoma antioncogene also results in skipping of exon 21 during mRNA biogenesis (24). Moreover, exon skipping caused by single base substitutions at the splice donor sites of exon 6 in the pro- $\alpha_{2}$ (I) collagen gene (25) and exon 12 of the porphobilinogen deaminase gene (26) has been shown to be responsible for one variant of an Ehlers-Danlos syndrome and acute intermittent porphyria, respectively. Our present results show that a similar process occurs in the liver of NARs, in which a mutated intron $\mathrm{H}-\mathrm{I}$ in the albumin primary transcript produces an albumin mRNA with an exon $\mathrm{H}$ deletion.

Inclusion or exclusion of certain exons occurs as a normal event during alternative splicing of specific primary transcripts (27); however, the mechanism by which such selections are made has not been fully elucidated. From analysis of exon exclusion due to mutational inactivation of flanking intron splice sites, certain predictions can be made regarding the mechanism of splice site selection. In studies to be reported elsewhere, we have demonstrated that skipping of

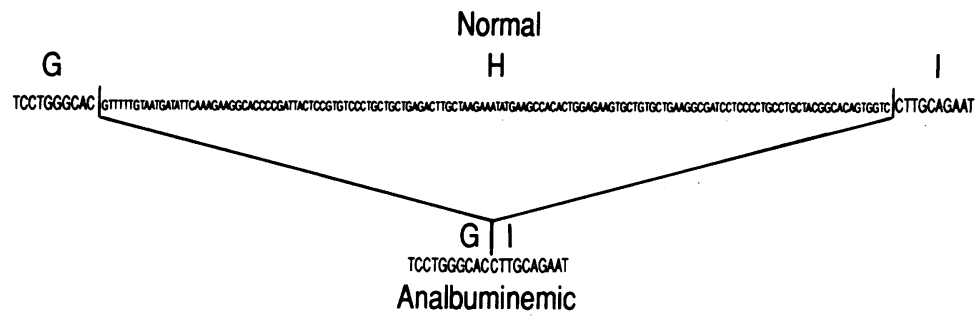

FIG. 6. Sequence analysis of PCR-amplified cDNAs. PCR amplification products obtained as described in Fig. 4 were subcloned into the $P$ st $\mathrm{I}$ and HindIII sites of the plasmid vector pGem-4Z and sequenced. The sequence of normal rat albumin cDNA is shown above with the exon $H$ region in smaller letters and the sequence of NAR albumin cDNA is shown below. 
exon $\mathrm{H}$ during splicing of albumin mRNA precursors in NAR liver involves excision of a lariat molecule containing exon $\mathrm{H}$ flanked by introns G-H and H-I. Since only the intron $\mathrm{H}-\mathrm{I}$ splice donor site is mutated (both the intron G-H splice donor and acceptor sites are normal), finding such a lariat is consistent with a scanning mechanism for splicing $(28,29)$, which in this case must occur in a $3^{\prime}$ to $5^{\prime}$ direction. This derives from the presumption that $5^{\prime}$ to $3^{\prime}$ scanning should lead to normal excision of intron $\mathrm{G}-\mathrm{H}$ and retention of all or part of intron $\mathrm{H}-\mathrm{I}$ in the mature mRNA. The latter depends on whether a downstream cryptic splice donor site within intron $\mathrm{H}-\mathrm{I}$ is utilized. Since an mRNA with retained intron $\mathrm{H}-\mathrm{I}$ sequences was identified only as a minor transcript, this implies at a minimum that scanning across the G-H-I region of the rat albumin pre-mRNA occurs more rapidly in a $3^{\prime}$ to $5^{\prime}$ direction as compared to a $5^{\prime}$ to $3^{\prime}$ direction. It should be noted, however, that some splice acceptor site mutations also lead to exon skipping (21-23) and this is consistent with $5^{\prime}$ to 3 ' scanning.

Deletion of exon $\mathrm{H}$ in NAR albumin mRNA causes a frame shift in the mRNA and generates a translation termination signal at the seventh codon of exon I. Consistent with earlier findings that nonsense mutations cause reduced levels of $\beta$-globin mRNA in $\beta$-thalassemia syndromes $(30,31)$, recent studies have shown that nonsense mutations in the triosephosphate isomerase and Rous sarcoma virus gag gene mRNAs lead to decreased mRNA stability $(32,33)$. This may explain the marked reduction in albumin mRNA in NARs. However, another study (21) reported no difference in the half-life of dihydrofolate reductase mRNA with a nonsense mutation compared to normal mRNA. These authors (21) proposed a block in processing, nuclear-cytoplasmic transport, or both to explain reduced levels of cytoplasmic dihydrofolate reductase mRNA in the mutant cells. The NAR model offers another system to study the effect of nonsense mutations on specific mRNA metabolism in a higher eukaryotic cell. Within this context, it is interesting that in the various cases of exon skipping mentioned above (21-26), there was no frame shift in the coding sequence and mRNA levels were very close to normal.

The genetic mutation in one case of human analbuminemia has been determined as a single base substitution changing the universal AG dinucleotide to GG at the $3^{\prime}$ end of intron 6(34). However, due to the inability to obtain liver RNA from this patient, the resulting mRNA was not characterized, although aberrant splicing was demonstrated in vitro. A similar problem is also encountered in studying splicing of $\beta$-globin transcripts in $\beta$-thalassemia patients, because the erythroid precursor cell becomes anucleate during the process of differentiation. Consequently, splicing of mutant mRNA precursors in $\beta$-thalassemia could only be studied either in vitro with cell-free extracts or after transfection and expression of the mutant gene in heterologous cell lines $(9$, 10). Since nuclear and cytoplasmic poly $(\mathrm{A})^{+}$and $\operatorname{poly}(\mathrm{A})^{-}$ RNA samples can readily be obtained from liver and the transcription rate of the albumin gene is at least as high in NARs as it is in normal rat liver (A. Panduro, G. Alpini, and D.A.S., unpublished data), the analbuminemic rat model offers an attractive system to study the mechanism of splicing in vivo in a higher animal species.

We thank Dr. S. Nagase for providing analbuminemic rats for these studies. Studies performed in this manuscript were in partial fulfillment of the requirements for a Ph.D. degree awarded to F.S. in the Sue Golding Graduate Division of Albert Einstein College of Medicine. This research was supported in part by Grants RO1 DK-17609 and P30 DK-41296 from the National Institutes of Health.

1. Peters, T., Jr. (1979) Adv. Clin. Chem. 13, 37-111.

2. Inoue, M. (1985) Hepatology 5, 892-898.

3. Boman, H., Hermodson, M., Hammond, C. A. \& Motulsky, A. G. (1976) Clin. Gen. 9, 513-526.

4. Nagase, S., Shimammuni, R. \& Seige, S. (1979) Science 205, 590-591.

5. Makino, R., Esumi, H., Sato, S., Takahashi, Y., Nagase, S. \& Sugimura, T. (1982) Biochem. Biophys. Res. Commun. 106, 185-193.

6. Esumi, H., Okui, M., Sato, S., Sugimura, T. \& Nagase, S. (1980) Proc. Natl. Acad. Sci. USA 77, 3215-3219.

7. Esumi, H., Takahashi, Y., Sekiya, T., Sato, S., Nagase, S. \& Sugimura, T. (1982) Proc. Natl. Acad. Sci. USA 79, 734-738.

8. Esumi, H., Takahashi, Y., Shigeaki, S., Nagase, S. \& Takahashi, S. (1983) Proc. Natl. Acad. Sci. USA 80, 95-99.

9. Treisman, R., Orkin, S. H. \& Maniatis, T. (1983) Nature (London) 302, 591-596.

10. Treisman, R., Proudfoot, N. J., Shander, M. \& Maniatis, T. (1982) Cell 29, 903-911.

11. Sargent, T. O., Jagodzinski, L. L., Yang, M. \& Bonner, J. (1981) Mol. Cell. Biol. 1, 871-883.

12. Busch, H. (1967) Methods Enzymol. 12, 421-448.

13. Chomczynski, P. \& Succhi, N. (1987) Anal. Biochem. 162, 156-159.

14. Aviv, H. \& Leder, P. (1972) Proc. Natl. Acad. Sci. USA 69, 1408-1413.

15. Melton, D. A., Krieg, P. A., Rebagliati, M. R., Maniatis, T. \& Green, M. R. (1984) Nucleic Acids Res. 12, 7035-7056.

16. Maniatis, T., Fritsch, E. F. \& Sambrook, J., eds. (1982) Molecular Cloning: A Laboratory Manual (Cold Spring Harbor Lab., Cold Spring Harbor, NY)

17. Feinberg, P. A. \& Vogelstein, B. (1983) Anal. Biochem. 132, 6-13.

18. Panduro, A., Shalaby, F., Weiner, F., Biempica, L., Zern, M. \& Shafritz, D. A. (1986) Biochemistry 25, 1414-1420.

19. Krainer, A. R. \& Maniatis, T. (1988) in Frontiers in Molecular Biology (IRL, Oxford), pp. 131-206.

20. Padgett, R. A., Grabowski, P. J., Konarska, M. M., Seiler, S. \& Sharp, P. A. (1986) Annu. Rev. Biochem. 55, 1119-1150.

21. Urlaub, G., Mitchell, P. J., Cuidad, C. J. \& Chasin, L. A. (1989) Mol. Cell. Biol. 9, 2868-2880.

22. Mitchelle, P., Urlaub, G. \& Chasin, L. A. (1986) Mol. Cell. Biol. 6, 1926-1935.

23. Tromp, G. \& Prockop, D. J. (1988) Proc. Natl. Acad. Sci. USA 85, 5254-5258.

24. Horowitz, J. M., Yandell, D. W., Park, S. H., Canning, S., Whyte, P., Buchkovich, K., Harlow, E., Weinberg, R. A. \& Dryja, T. P. (1989) Science 243, 938-940.

25. Weil, D., Bernard, M., Combates, N., Wirtz, M. K., Hollister, D. W., Steinmann, B. \& Ramirez, F. (1988) J. Biol. Chem. 263, 8561-8564.

26. Grandchamp, B., Picat, C., deReeij, F., Beaumont, C., Wilson, P., Deybach, J. C. \& Nordmann, Y. (1989) Nucleic Acids Res. 17, 6637-6649.

27. Breitbart, R. E., Andreadis, A. \& Nadal-Ginard, B. (1987) Annu. Rev. Biochem. 56, 467-495.

28. Lewin, B. (1980) Cell 22, 324-326.

29. Sharp, P. A. (1981) Cell 23, 643-646.

30. Takashita, K., Forget, B. G., Scarpa, A. \& Benz, J., Jr. (1984) Blood 64, 13-22.

31. Humphries, K., Ley, T. J., Anagnou, N. P., Baur, A. W. \& Nienhuis, A. W. (1984) Blood 64, 23-32.

32. Daar, I. O. \& Maquat, L. E. (1988) Mol. Cell. Biol. 8, 802-813.

33. Arrigo, S. \& Beemon, K. (1988) Mol. Cell. Biol. 8, 4858-4867.

34. Ruffner, D. E. \& Dugaizyk, A. (1989) Proc. Natl. Acad. Sci. USA 85, 2125-2129. 